\title{
How to Manage Urban Tourism of Kampung Sumbawan, Krapyak, Pekalongan: A SWOT Analysis and Related Strategies
}

\author{
Rina Suprina ${ }^{1}$, Agie Pradhipta $^{2}$ and Purwanti Dyah Pramanik ${ }^{3}$ \\ 123 Sekolah Tinggi Pariwisata Trisakti, Jakarta, Indonesia
}

Email: ${ }^{1}$ rinasuprina@stptrisakti.ac.id, ${ }^{2}$ agiepradhipta@ stptrisakti.ac.id, and ${ }^{3}$ purwanti@ stptrisakti.ac.id

\begin{abstract}
Urban tourism is going to be an important tourism activity in the world. Pekalongan, a small city in Central Java, is famous for its cultural heritage. One of the areas which is potentially developed to be a tourist destination is Kampung Sumbawan. The purpose of this paper is to find out and suggest how to manage urban tourism of Kampung Sumbawan in Krapyak, Pekalongan through SWOT analysis. 15 people participated in Focus Group Discussion (FGD). They are representatives from local governments, media, academicians, and local community from Kampung Sumbawan. This study used the research methods of SWOT analysis to investigate the internal ressources (strength and weaknesses) and external environment (opportunities and threats). Based on the SWOT analysis, the positioning of Kampung Sumbawan could be predicted and the strategy can be decided. The research found that the appropriate strategy to develop Kamping Sumbawan is by doing improvement strategy, especially in improving product and service there, and joint venture with other parties.
\end{abstract}

Keywords-Urban tourism, SWOT analysis, strategies

\section{INTRODUCTION}

Pekalongan is a small city in Central Java which has potentials to be developed as tourist destination. Therefore, Trisakti School of Tourism and the Mayor of Pekalongan signed Memorandum of Understanding (MoU) to achieve the purpose. The activity began with the assignment of some students from Trisakti School of Tourism to work for one month in two tourism village, namely Kampung Batik Kauman and Kampung Batik Pesindon in order to develop the areas to be more ready for tourist destination. After that the collaboration continued by conducting tourism training to the employees of the Pekalongan Tourism Office. Then the Head of Tourism Office gave information about one of the areas in Pekalongan, well known for the woven clothe product, namely Kampung Sumbawan. This area is going to be developed to be another tourist destination.

According to Eko Kalungguh, the central figure in Kampung Sumbawan, Kampung Sumbawan was formed due to the trade winds of the archipelago around 300 to 250 years ago in Pekalongan. As a coastal area, at that time the trade to and from Pekalongan was conducted through sea transportation, namely through Kupang river or now known as Loji river. The traders or merchants who entered Pekalongan came from various parts of Indonesian archipelago such as Banjar Kalimantan, Sampang Madura, Bugis Sulawesi, Pesundan West Java, and Sumbawa West Nusa Tenggara. They entered Pekalongan through the route of Kupang River. As a result, on the banks of Kupang River there are several names of areas taken from the origin of merchants who trade in Pekalongan, one of them is Kampung Sumbawan.

In Kampung Sumbawan there is an old tomb known as the tomv of Mbak Wayah. According to the legend, this is the grave of Kiyai Yahya, a cleric from Sumbawa who built the mosque in Krapyak area, Pekalongan. He was famous for his fighting spirits against the invaders and he was believed to be the one who opened the opportunity of trades from Sumbawa to Pekalongan, especially to the region of Kampung Sumbawan. As a result, there were many traders from Sumbawa who domiciled in Kampung Sumbawan. Currently Kampung Sumbawan is divided into 2 RW and 13 RT.

Based on the information from local government of Pekalongan and community leader in Kampung Sumbawan, they palan to develop Kampung Sumbawan to be a tourist destination which has a similar capacity as other tourism villages such as Kampung Batik Kauman and Kampung Batik Pesindon. The first step to make the dream comes true is to mapping Kampung Sumbawan by 
conducting Focus Group Discussion (FGD) with the stakeholders of Kampung Sumbawan. By doing FGD, the information of strengths, weaknesses, opportunities, and threats could be collected.

\section{A. Urban Tourism}

\section{LITERATURE REVIEW}

Not many tourism experts reveal the definition of urban tourism. Klingner (2006: 1) defines urban tourism as simple as "a set of resources or tourist activities are located in the city and offer it to visitors from other places". Another definition put forward by Inskeep (1991: 163) which emphasizes the role of tourism in urban areas as follows: "Urban tourism a very common form of tourism takes place in large cities where tourism may be important but is not a primary activity of the urban area" (Inskeep, 1991: 162). Referring to the definitions outlined previoiusly, urban tourism can be defined as common form of tourism which utilizes elements of urban (non-agricultural) and all things associated with aspects of city life as a tourist attraction.

Page (2003: 27) argues that urban tourism grew as a result of the globalization of the economy in the late 1970s. The globalization changes the structure of the world economy, integrates the structure of the national economy into the structure of the international economy in the form of trade, foreign investment, migration, and technology. Interstate relations in the early 1980s increased more interactive, multipolar, and highly interdependent circumstances. This resulted in the pattern of decentralized economic organization on a global scale so that the autonomy of cities on the economy declined. It is this condition that causes deindustrialization in urban areas that generate investment in a very large service industry, particularly those associated with consumption, at the end of the 20th century and early $21 \mathrm{st}$ century. Then, the dominance of the service industry is the hallmark of cities today (Page, 2003: 27). The high investment in the service industry (Page, 2003: 27) motivated the city governments to develop tourism as a major stimulus to local and regional economic improvements (Roche, 1992 in Page, 2003: 28). Tourism is also expected to spur changes in urban political conditions so as to revive the attractiveness of the environment for investment (Doorne, 1998 in Page, 2003: 28).

The demand for travel to cities has greatly increased over the last few decades. People travel for different reasons: some are traveling for business purpose, others are travelling on their free time to study about other cultures, to develop their specific interests, and to find entertainment. Law (2002) examines the relationship between tourism and urban areas. He distinguishes between primary, secondary, and additional elements of a city's tourism resources. Primary elements provide the main reasons why tourists visit cities. Secondary elements such as accommodation and shopping as well as additional elements like transportation or tourist information are also very important for the success of urban tourism, but are not the main attractor of visitors.

\section{B. SWOT Analysis}

SWOT analysis is one of the tools to decide strategy based the environment of the organization (Phadermrod et al: 2017). SWOT is the abbreviated of English: strength, weakness, opportunity, and threat (Yogi, et al: 2007 \& Zhang 2012)]. Internal analysis is effective for analizing tourist attraction (Zhang, Q: 2012).

By analyzing the external and internal environment of the organization, there can be created a strategy that must be taken by the organization. Figure 1 explains the strategy in general. First of all, if the organization has a high opportunity and strength, the organization can implement expansive strategy. Secondly, if the organization has a high threat but a high strength, the organization is suggested to decide diversification strategy. Thirdly, if the organization has a high opportunity but has a high weakness, the organization strategy is suggested to improve internal situation. Fourthly, if the organization has a high threat and weakness, its strategy must be defensive strategy.

TABLE I. STRATEGY IN GENERAL 


\begin{tabular}{llll}
\hline & & & \multicolumn{2}{c}{ Internal } \\
\cline { 2 - 4 } External & Opportunity & Aggressive & Weakness \\
\cline { 2 - 4 } & & Strategy & Improvement \\
& Threat & Diversification & strategy \\
& & Defensive strategy & \\
\hline
\end{tabular}

\section{General Strategy Types}

The type of general strategy: (1) concentration growth strategy; (2) market and product development; (3) horizontal and vertical integration; (4) concentric diversification; (5) conglomerate diversification; (6) innovation; (7) improvement strategy; (8) joint venture; (9) alliance strategic; (10) consortium; (11) defensive; (12) devastation; and (13) liquidation.

Concentration growth strategy is a strategy that focuses all resources to grow a product/ service or a certain market based on its competitive advantages. This strategy can be implemented as follow:

(a) Improve the use of product or service of the existing consumers.

How to improve the consumption of the existing consumers? There are four ways. The first, increase the number of consumers' consumption. The second accelerate product/ service obsolescence. The third, introduce the new way of using product. The fourth, provide price incentives for higher product usage.

(b) Attract the attention of competitors' consumers.

In order to attract the attention of competitors' consumer, there must be clarify product differentiation, boost promotion, and provide discount.

(c) Grab the new consumers.

Grab the new consumers can be done by stimulating the desire to try the product through product sampling, price incentives, and rewards. Other ways are giving discount, doing promotion and advertisement.

There are some conditions that will support and won't support to implement concentration growth strategy. The supported situation are: Firstly, the organization has competitive advantages. Secondly, there isn't technology threat. It means that it's easy to have technology so that the service will be provided without any problem. Thirdly, the market is not yet saturated. Fourthly, there is stable supplier. And the unsupported situation are: Firstly, changes in products, markets, technology, economic and industrial environments. Secondly, saturated markets, small market, and opportunistic opportunities.

Market and product development is a strategy to expand the existing market. The (of market and product) can be done by opening new geographic market, such as national, regional, international expansion, or broaden other market segment for example develop new products or services, distribution channels, and promotion. Developing products or services can also be settled by doing modification based on sizes, quality levels, and even create new products or services.

Horizontal and vertical integration is developing organization by establishing business development forward or backward. The illustration of vertical and horizontal integration is shown in figure 2 .
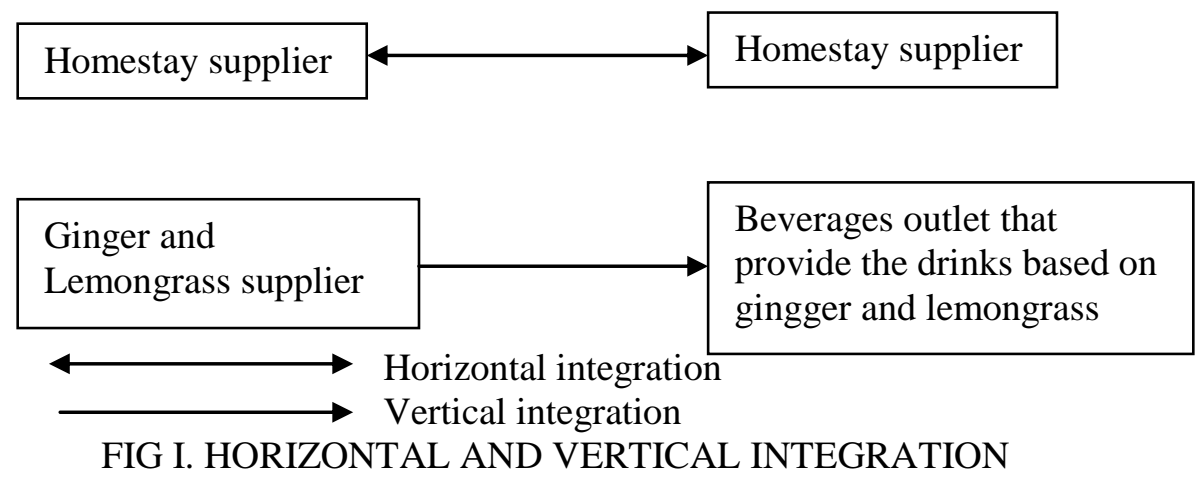

Horizontal integration is expanding the organization to the similar business, for example the person who has a homestay and then built another homestay. Vertical integration is developing the organization to the different business but it is for supporting the existing business, such as the supplier 
of ginger and lemongrass establishes beverage outlet that provide the drinks that is prepared from ginger and lemongrass. Medical tourism is going to be a potential vertical integration in tourism (Harrison and Cathy 2012)

Concentric diversification is a strategy by establishing the business that has relationship to the existing business according to product, technology, and market. This strategy is suitable for the business which has the threat but there good opportunities in other business (Ganguli \& Ahmed : 2017).

Conglomerate diversification is a strategy by creating others business that doesn't have any linkages to the existing business. This strategy is fit if there good opportunities in other business and the existing product or service is under threat. Innovation is a strategy by launching new products, technologies, or markets. This is done to increase opportunities and avoid threats to existing products. Improvement strategy is suggested for the business that has the number of deficiencies. Joint venture is advised for the business that wants to reach the big opportunity and it can be handled only if the two or more parties are cooperated. Alliance strategy is the strategy that has temporary cooperation to reach the goal. Consortium is a strategy by cooperating with many companies through a giant connectivity to seize common opportunities. Defensive is a strategy to endure the business. Devastation is selling the business partially. Finally, liquidation is selling all the business.

\section{Strategy Mapping}

The strategies mapping can be describes in table II.

TABLE II. STRATEGIES IMPLEMENTATION

\begin{tabular}{|c|c|c|c|}
\hline \multirow{10}{*}{ External } & & \multicolumn{2}{|c|}{ Internal } \\
\hline & & Strength & Weakness \\
\hline & \multirow[t]{5}{*}{ Opportunity } & 1. Concentration growth & 1. Improvement strategy \\
\hline & & strategy & 2. Joint venture \\
\hline & & 2. Market and product & 3. Alliance strategic \\
\hline & & development & 4. Consortium \\
\hline & & $\begin{array}{l}\text { 3. Horizontal and vertical } \\
\text { integration }\end{array}$ & \\
\hline & \multirow[t]{3}{*}{ Threat } & 1. Concentric diversification & 1. Defensive \\
\hline & & 2. Conglomerate diversification & 2. Devastation \\
\hline & & 3. Innovation & 3. Liquidation \\
\hline
\end{tabular}

\section{METHODS}

\section{A. Data}

The data was collected/generated by doing FGD. The FGD participants are fifteen people involved in the development of urban tourism in Pekalongan where Kampung Sumbawan is located. They are the representatives from The Office of Tourism, Culture, Youth and Sports (Head of Depaartment, Head of Tourism Division, Human Resources and Marketing), blogger community, Leader from Kampugn Sumbawan, Head of LPM, Head of organization called KOTAKU, Head of Promotion Body Pekalongan, and Head of Krapyak Regency. FGD was held on August 25, 2017 and the observation was held on August 26, 2017. The FGD was held in village secretariat of Pekalongan disctrict.

\section{B. Method}

The research was conducted using SWOT analysis methods. The information from FGD activity was categorized into strength, weakness, opportunity, and threat. The point of 4 to 0 is used to rate opportunity and strength and -4 to 0 is used to rate threat and weakness. Then multiply weight and rating to get the point. Add up the point to know opportunity and threat position. Do the same thing for strength and weakness. Next, formulate general strategy into operational objectives.

\section{RESULT AND DISCUSSION}

\section{A. Result}

Kampung Sumbawan has some strengths and weaknesses. The strengths are as follow: 
1. Product and creativity industry

Kampung Sumbawan is famous for woven clothes and Pekalongan Batik. Pekalongan has achieved an award of World UNESCO Heritage 2009 for 2 categories. They are Pekalongan Batik for the category of non-object world heritage and Pekalongan Batik Museum for the category of World heritage objects. Jamplrang is an icon of batik motif from Pekalongan. Besides batik and woven clothes, Kampung Sumbawan also has specific culinary such as Lopis, Kue coro, Kopi Tahlil, Minet So, Nasi Megono, Tauto \& Soto, Pindang srani and Calon. Kampung Sumbawan has some creative industry run by the community. The products are unique and authentic. Woven cloth of Sumbawan is a superior and inherent product that can not be found elsewhere. There are also Batik craftsmen community, Bamboo Boat Replica, and so forth.

2. Culture and Traditions

The village of Krapyak especially Kampung Sumbawan has a cultural event calendar 4 times a year:

a. Syawalan with lopis cake.

b. Rebo with choro cake

c. Suronan with suro porridge

d. Nisfu sakban night held 15 days before the fasting month (Ramadan)

In addition there is martial arts or kuntulan, terbang maulid and musical performance called tongprek in the dawn during ramadhan done by many children and adolescents to enliven Ramadan.

3. Location

Kampung Sumbawan is in Strategic Location. Near Batik Museum It's located in downtown Pekalongan, so it's easy to access by various modes of transportation. It's also located at the Kupang river bank which is one of the access of the main route of the past from the sea to the city of Pekalongan. This situation can be developed activities of mangrove tourism and Dinner Cruise.

Social community There is a strong mutual community tradition among Kampung Sumbawan people. They are close to each other.

4. Respected leader

The presence of community leaders who act as a respected and respected role model / leader.

5. Infrastructure

Basic infrastructure already available: water supply, PLN, sewerage, drainage. Visitor facilities and services available: walkways, food stalls, mosque, mosque, security post, fire extinguisher, wagon carts, fishing attractions, folk games and boat tours.

The weaknesses are:

1. Young generation: The low interest of young generation in Pekalongan City, especially in Kampung Sumbawan).

2. Image: the neighborhood seems grungy and not well laid out.

3. Cleanliness: healthy clean lifestyle (PHBS) has not been well implemented due to low public awareness. It's related to the previous research in Iran that tourism activities is oppossed sustainability (Reihanian et all, 2012)

4. The economic level of society is still low.

5. Lack of Confidence: low self-esteem because it feels marginalized.

6. Waste management (hygiene) is not optimal, especially the number of household waste (garbage) and water hyacinth on the banks of the Kupang river. Frequent ROB floods occur when sea levels are high. Urban green is urgent to keep people healthy (TK Khostaria, 2017)

7. Education: The low level of education of the average community of Kampung Sumbawan (average elementary school graduate).

8. Tourism awareness (Sapta Pesona): the community has not understood the tourism awareness, excellent service and sapta charm.

9. Product quality: products that have not been optimal due to low knowledge and direct access to the market and the absence of quality standard quality of handicraft products of 
society. Basic infrastructure that is not yet available or needs to be repaired: clean water treatment plant, clean water reservoir, generator, greening.

10. Visitor facilities

Visitor facilities and services that are not yet available or need improvement:

sidewalks, homestays, restaurants, historical and cultural museums (but there is already a batik museum), picnic parks, water sports, boat tours already there but need to be made better.

On the other hands, Kampung Sumbawan has some opportunity and threat. The opportunities are:

1. Accessibility: There is Toll Cipali - Semarang/ Trans Java will be built, exit toll Pekalongan which can be made easy to access to Kampung Sumbawan; The role of Kupang riveras access to water transportation to Kampung Sumbawan , Krapyak; Kertajati Majalengka International Airport will be built, and this airport can be accessed for international tourists who want to visit the village of Sumbawan; and there is also Pekalongan City railway is the main route of trans Java rail transport.

2. Funding: there is utilization of village funds as a source of facilities development costs; Utilization of CSR funds (Corporate Social Responsibility) mandated by the Act against the environment; PNPM Program (National Community Empowerment Program) related to various fields. One of them is PNPM Tourism.

3. World UNESCO Heritage event is being the opportunity for the villages (include Kampung Sumbawan) to show their advantage in heritage.

Besides those opportunities, Kampung Sumbawan has threats. It's the competitor. The competitor has strong capital and marketing support, similar products, mass production. In the city of Pekalongan out of Kampung Sumbawan, there are many centers of batik craftsmen; The existence of capital support and marketing network at for other batik craftsmen; The similar batik product style are produced out of Kampung Sumbawan; The implementation of technology and mass production (large scale industry) deadly small craft industry community (home industry); The low interest of young generation in Pekalongan City, especially in Kampung Sumbawan. Short distance tourism is popular (Yu-Tsun Liao, 2015). It becomes a lifestyle. On the other hand the development of cultural tourism depends on society participation (Korunoyski dan Naume; 2012).

Table III describe the condition of external (opportunity and threat) and internal situation (strength and weakness) of Kampung Sumbawan in Pekalongan. 
TABLE III. SWOT ANALYSIS OF KAMPUNG SUMBAWAN IN PEKALONGAN

\begin{tabular}{|c|c|c|c|c|c|c|}
\hline Aspect & Impact & Rate1 & Percentage & Proportion & Rate2 & Values \\
\hline \multicolumn{7}{|l|}{ Opportunity } \\
\hline 1. Accessibility: toll road, water transportation, international airport. & Very high & 4 & 28.57 & 0.2857 & 4 & 1.1428 \\
\hline 2. Funding: village funds, CSR, and PNPM Tourism. & Very high & 4 & 28.57 & 0.2857 & 4 & 1.1428 \\
\hline 3. World UNESCO Heritage event & Very high & 4 & 28.57 & 0.2857 & 4 & 1.1428 \\
\hline $\begin{array}{l}\text { Threat } \\
\text { 1. Competitor: strong capital and marketing support, similar products, mass } \\
\text { production. }\end{array}$ & Fair & 2 & 14.29 & 0.1429 & -2 & -0.2858 \\
\hline $\begin{array}{l}\text { Total }(\mathbf{O}-\mathbf{T}) \\
\text { Strength }\end{array}$ & & 14 & 100 & & & 3.1426 \\
\hline 1. Product. & High & 3 & 4.99 & 0.1765 & 3 & 0.5295 \\
\hline 2. Strategic Location. & Very high & 4 & 6.66 & 0.2353 & 4 & 0.9412 \\
\hline 3. Creative Industry . & Fair & 2 & 3.33 & 0.1176 & 2 & 0.2352 \\
\hline 4. Local specialties & High & 3 & 4.99 & 0.1765 & 3 & 0.5295 \\
\hline 5. Culture & High & 3 & 4.99 & 0.1765 & 3 & 0.5295 \\
\hline 5. Social community & Very high & 4 & 6.66 & 0.2353 & 4 & 0.9412 \\
\hline 7. Respected leader & Very high & 4 & 6.66 & 0.2353 & 4 & 0.9412 \\
\hline 3. Infrastructure & Very high & 4 & 6.66 & 0.2353 & 4 & 0.9412 \\
\hline Weakness & & & & & & \\
\hline э. Young generation & High & 3 & 4.99 & 0.1765 & -3 & -0.5295 \\
\hline 10.Image & Very high & 4 & 6.66 & 0.2353 & -4 & -0.9412 \\
\hline 11.Cleanliness & Very high & 4 & 6.66 & 0.2353 & -4 & -0.9412 \\
\hline 12.Economic level & High & 3 & 4.99 & 0.1765 & -3 & -0.5295 \\
\hline 13.Confidence & Very high & 4 & 6.66 & 0.2353 & -4 & -0.9412 \\
\hline 14.Education & High & 3 & 4.99 & 0.1765 & -3 & -0.5295 \\
\hline 15.Tourism awareness (Sapta Pesona) & Very high & 4 & 6.66 & 0.2353 & -4 & -0.9412 \\
\hline 16.Product quality & Very high & 4 & 6.66 & 0.2353 & -4 & -0.9412 \\
\hline 17. Visitor facilities & Very high & 4 & 6.66 & 0.2353 & -4 & -0.9412 \\
\hline Total $(\mathbf{S}-\mathbf{W})$ & & 60 & 100 & & & -1.6472 \\
\hline
\end{tabular}


External Environment

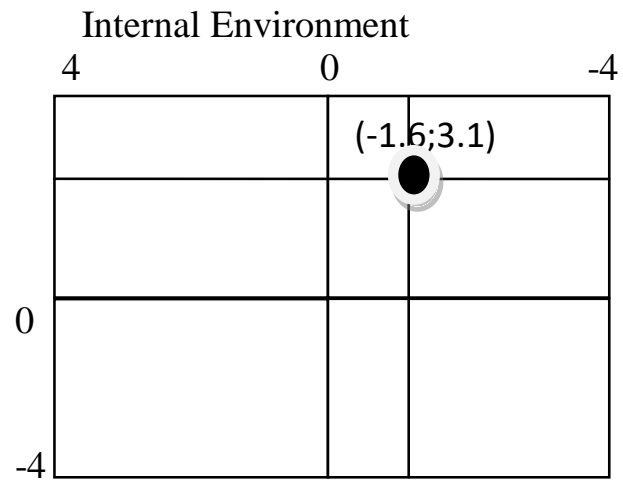

FIG II. STRATEGY DECISION

According to the result above, the strategy suggested is improvement strategy internally. To implement the strategy, operational strategy must be decided. It is shown in table IV.

TABLE IV. OPERATIONAL STRATEGY

\begin{tabular}{|c|c|c|}
\hline & $\begin{array}{l}\text { Strength: } \\
\text { 1. Strategic Location. } \\
\text { 2. Creative Industry. } \\
\text { 3. Local specialties } \\
\text { 4. Culture. } \\
\text { 5. Social community. } \\
\text { 5. Respected leader. } \\
\text { 7. } \text { Infrastructure. }\end{array}$ & $\begin{array}{l}\text { Weakness: } \\
\text { 1. Young generation. } \\
\text { 2. Image. } \\
\text { 3. Cleanliness. } \\
\text { 4. Economic level. } \\
\text { 5. Confidence. } \\
\text { 6. Education. } \\
\text { 7. Tourism awareness (Sapta Pesona) }\end{array}$ \\
\hline $\begin{array}{l}\text { Opportunity: } \\
\text { 1. Accessibility } \\
\text { 2. Funding } \\
\text { 3. World UNESCO } \\
\text { Heritage event }\end{array}$ & $\begin{array}{l}\text { (S-O) } \\
\text { Establish: } \\
\text { World city of batik } \\
\text { Kampung wisata batik and weaving } \\
\text { Educational tour learn batik and weave } \\
\text { - Pilgrimage tour to the sheikh's grave } \\
\text { - Lupisan march each beginning of Syawal. } \\
\text { - Improvement of road facilities. } \\
\text { - Integrated local transportation system } \\
\text { (shuttle service, feeder). } \\
\text { Vehicle rental facilities (motorcycles, cars, } \\
\text { bicycles) } \\
\text { - Tourist information center } \\
\text { Sanitary Facilities (toilet, trash can, waste } \\
\text { treatment plant, centra culinary). } \\
\text { Home stay. } \\
\text { Porter service. } \\
\text { Medical center. } \\
\text { Guides services. } \\
\text { Theaters. } \\
\text { The marketing gallery of the community } \\
\text { craft industry. } \\
\text { - Money changer. } \\
\text { Sports field facility. } \\
\text { Adequate parking space. }\end{array}$ & $\begin{array}{l}\text { (W-O) } \\
\text { in creative industry. } \\
\text { Re-use plastic waste. } \\
\text { - Empower people to participate: } \\
\checkmark \text { Tours education crafts based on eceng } \\
\text { gondok. } \\
\checkmark \text { City farming tour. } \\
\checkmark \text { Bird games. } \\
\checkmark \text { Boat tour. } \\
\text { - } \\
\text { Establish waste processing installation. } \\
\text { Implementation of siskamling and } \\
\text { kamtibmas. }\end{array}$ \\
\hline $\begin{array}{l}\text { Threat: } \\
\text { Competitor: strong } \\
\text { capital and marketing } \\
\text { support, similar } \\
\text { products, mass } \\
\text { production. }\end{array}$ & $\begin{array}{l}\text { (S-T) } \\
\text { Learning how to weave sumbawan motif. } \\
\text { The class facilities to educate tourism. } \\
\text { Local culinary center } \\
\text { Ict / wifi / warnet. } \\
\text { Establish pokdarwis. } \\
\text { Quality standards of service. }\end{array}$ & $\begin{array}{l}\text { (W-T) } \\
\text { Train the people of tourism awareness } \\
\text { and Sapta pesona. } \\
\text { Benchmark from the competitor. } \\
\text { Strengthen social capital. } \\
\text { Empower the people (include young } \\
\text { people) to create unique product. }\end{array}$ \\
\hline
\end{tabular}


Table IV describes operational strategy. Finally, operational objectives must be completed to measure the progress. Table $\mathrm{V}$ shows the operational objective.

TABLE V. OPERATIONAL OBJECTIVES

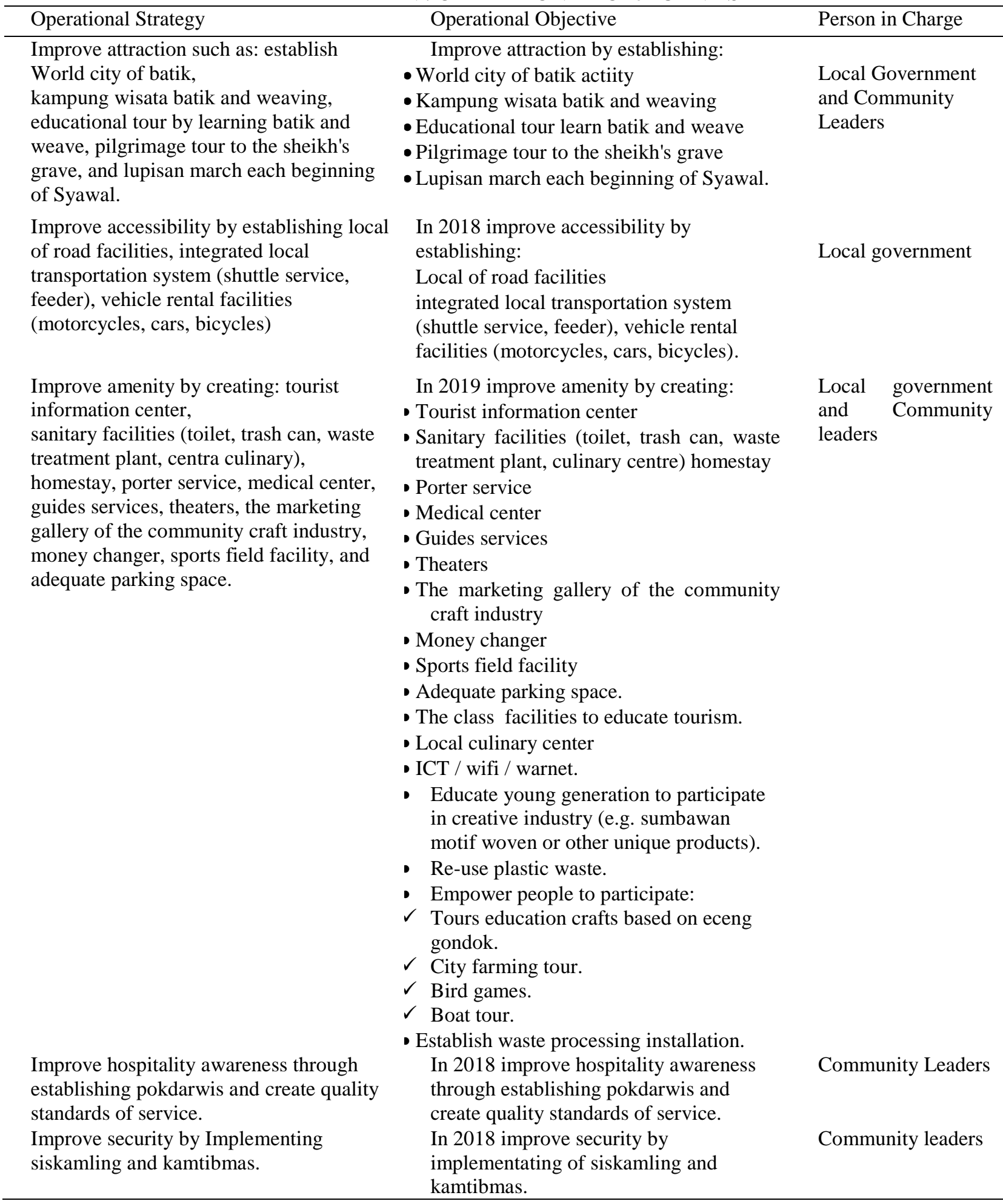

\section{CONCLUSION}

Kampung Sumbawan has a great potential to be developed as a tourist destination. The result of the research found that the appropriate strategy to develop Kamping Sumbawan is by doing improvement strategy, especially in improving product and service there, and joint venture with other parties. Kampung Sumbawan has a strong leader who has been accepted by the community so that it will be much easier to 
develop the area. Joint venture can be established with companies which can help improving physical conditions of the village (e.g paint company to color the houses and make murals), and with education institutions to improve the human resources qualities.

Acknowledgment: This research is fully supported by Sekolah Tinggi Pariwisata Trisakti.

\section{REFERENCES}

Ashworth G.J. dan Tunbridge, J.E. (1990): The Tourist-Historic City, John Wiley\&Sons, England.

Ganguli S., dan Ahmed, H.E.," A qualitative analysis of Singapore's medical tourism competitiveness Subhadra Ganguli,"Tourism Management Perspectives 21, 74-84 (2017).

Harrison J.S. dan Cathy A.E.,"Hospitality Strategic Management: Concepts and Cases, ”New Jersey: John Wiley \& Sons.

Inskeep, Edward, (1991): Tourism Planning- An Integrated Sustainable Approach, Van Nostrand Reinhold, New York.

Korunovski, S., dan Naume M.," Cultural tourism in Ohrid as a selective form of tourism development," Procedia - Social and Behavioral Sciences 44, $104-113(2012$ ).

Law, Christopher M. (1996): Tourism in Major Cities, International Thomson Business Press, London.

Page, Stephen J. dan Hall, Michael C., (2003). Managing Urban Tourism, Pearson Education Limited, Harlow.

Phadermrod B., Richard M.C., dan Gary B.W.," Importance-Performance Analysis Customer based SWOT Analysis," International Journal of Information Management, 1-10 (2017).

Reihanian A., Noor Z.binti M, dan Tan W.H.," Sustainable tourism development strategy by SWOT analysis: Boujagh National Park, Iran,"Tourism Management Perspectives 4, 223-228(2012).

Richard, Greg dan Wilson, Julie (2007): Tourism, Creativity, and Development, Routledge, Oxon.

T.K. Khoshtaria, dan T.K. Khoshtaria," The planning of urban green areas and its protective importance in resort cities (case of Georgian resorts),"Annals of Agrarian Science 15, 217-223 (2017).

Yu-Tsun Liao," Strategic ecocity development in urban-rural fringes: Analyzing Wulai District,"Sustainable Cities and Society 19, 98-108(2015).

Yogi, Adang W, Sudrajati, R., dan Lamansu L, "Manajemen Stratejik Terapan: panduan Cara Menganalisa Industri \& Pesaing. ”Jakarta: Poliyama Widya Pustaka, 2007.

Zhang X.M.,"Research on the development strategies of rural Tsuzhou Based on SWOT Analysis,"Energy Procedia 16, 1295-1299(2012).

Zhang, Q," Research on Tourist Attractions Performance Promoting Method Based on the SWOT Analysis

Method," IERI Procedia 1, 254-260 ( 2012 ). 